\title{
Zmiany w podatku VAT w kontekście przeciwdziałania zjawisku unikania i uchylania się od opodatkowania w latach 2016-2018
}

\begin{abstract}
Robert Wolański*
Przedmiotem artykutu sa normatywne zmiany $w$ podatku VAT wprowadzone $w$ latach 2016-2018, majace na celu przeciwdziałanie zjawisku unikania $i$ uchylania się od tego podatku. Celem opracowania jest określenie przyczyn oraz sposobów wprowadzania tych zmian, a także skutków ich wprowadzenia. Dla realizacji celu jako metody badawcze wykorzystano przeglad wybranej literatury, aktów prawnych i danych statystycznych dotyczacych unikania $i$ uchylania się od opodatkowania. Za wynik tej analizy należy przyjąc potwierdzenie następujacych hipotez: zwiększenie dochodów budżetowych poprzez zmniejszanie luki podatkowej można osiagną́, gtównie uszczelniajac system poboru podatku VAT; zmiany w podatku VAT prowadza do zmniejszenia skali unikania i uchylania się od tego podatku, jednocześnie znacznie komplikuja stosowanie i rozliczanie tego podatku; negatywne skutki wprowadzonych zmian dla mikroprzedsiębiorstw i malych przedsiębiorstw.
\end{abstract}

Słowa kluczowe: podatek VAT, unikanie, uchylanie, opodatkowanie.

Nadesłany: 02.06.18 | Zaakceptowany do druku: 04.11.18

\section{Changes in Value Added Tax in the Context of Counteracting Tax Avoidance and Tax Evasion at Years 2016-2018}

The article discusses the problem of legal changes in VAT introduced in 2016-2018, which counteracting the avoidance and evasion of this tax. The purpose of this article is to determine causes, methods and effects of introducing these changes. To realize the purpose of article, as a research method, used the overview of selected literature, legal acts and statistical data on tax evasion and avoidance. As the result of the article is the verification of following thesis: the legitimacy of choosing VAT to reduce the tax gap, simultaneously increasing budget revenues; changes in VAT lead to a reduction of avoidance and evasion, at the same time greatly complicate the application and settlement of this tax; negative effects of introduced changes for the smallest enterprises (especially micro and small).

Keywords: VAT, avoidance, evasion, taxation.

Submitted: 02.06.18 | Accepted: 04.11.18

JEL: M21

\footnotetext{
* Robert Wolański - dr hab., Wydział Zarządzania Uniwersytet Warszawski. https://orcid.org/0000-00022460-6344.

Adres do korespondencji: Wydział Zarządzania, Uniwersytet Warszawski, ul. Szturmowa 1/3, 02-678 Warszawa; e-mail: rwolanski@wz.uw.edu.pl.
} 


\section{Wprowadzenie}

„Dążenie podatników do redukcji lub całkowitego zniwelowania obciążeń podatkowych jest zjawiskiem naturalnym, gdyż celem racjonalnie zachowującego się podatnika, zwłaszcza będącego przedsiębiorca, jest maksymalizacja zysku przy jednoczesnej minimalizacji strat” (Kuźniacki, 2012, s. 31).

„Takie zachowania przedsiębiorców prowadzą do zwiększenia zasobów środków finansowych podatników, które mogą być wykorzystane w pierwszej kolejności do zachowania bieżącej płynności finansowej, a następnie do inwestowania" (Brzeziński, 2003, s. 67).

Jednocześnie, zgodnie z art. 84 Konstytucji RP każdy jest zobowiązany do ponoszenia danin publicznych, w tym podatków określonych w ustawie. Około $90 \%$ wpływów do budżetu pochodzi właśnie z podatków. Wśród nich największe znaczenie ma podatek od towarów i usług (VAT), który dostarcza ponad $45 \%$ dochodów budżetowych. Dlatego też oczywiste jest, że państwo strzeże należnych dochodów podatkowych. Interesy fiskalne państwa powodują podejmowanie działań ograniczających zjawiska unikania i uchylania się od opodatkowania, szczególnie w odniesieniu do podatku VAT.

Generalnie państwo dąży do uzyskania jak największych wpływów do budżetu. Podatnicy z kolei starają się prowadzić politykę oszczędzania na podatkach. Biorąc pod uwagę, że podatek VAT ma główne znaczenie w zasilaniu dochodów budżetowych, za ważny temat należy przyjąć określenie działań państwa w zakresie podatku VAT nakierowanych na zmniejszenie unikania i uchylania się od tego podatku oraz ustalenie przyczyn, sposobów, skutków tych działań.

Celem artykułu jest określenie przyczyn oraz sposobów wprowadzania tych zmian, a także skutków ich wprowadzenia.

Dla realizacji celu jako metody badawcze wykorzystano przegląd wybranej literatury, aktów prawnych oraz danych statystycznych dotyczących unikania i uchylania się od opodatkowania.

\section{Podatek VAT w kontekście unikania i uchylania się od opodatkowania}

Prowadzenie działalności gospodarczej niesie ze sobą konieczność spełnienia wielu wymogów, wśród których jest pono- szenie ciężaru podatków. Zasada wolności gospodarczej ${ }^{1}$ mówi jednak, że każdy ma prawo sam ustalać rodzaj prowadzonej działalności, jak również jej zakres i sposób prowadzenia. Stąd można wysnuć wniosek, że „każdy przedsiębiorca tak może kształtować swoje sprawy, aby związane z nimi obciążenia podatkowe były jak najniższe" (Larkins, 1991, s. 472). „Istnieje zasada wolności unikania opodatkowania, która mówi, iż każdy ma prawo tak kształtować okoliczności faktyczne, aby nie stanowiły one urzeczywistnienia normatywnego stanu faktycznego, z którym ustawa wiąże opodatkowanie" (Tipke i Kruse, 1996, s. 121 za: Karwat, 2002, s. 34). Jednak, jak słusznie podkreśla się w literaturze, „unikanie podatku poprzez nadużycie możliwości kształtowania stosunku prawnego stanowi jednak przekroczenie granic wolności unikania opodatkowania" (Karwat, 2002, s. 34) - „unikanie opodatkowania to nadużycie prawa podatkowego - działanie zgodne $z$ literą prawa, lecz sprzeczne z jego duchem, z celem przepisu" (Filipczyk, 2017, s. 29).

Podstawowe znaczenie w omawianym dylemacie ma motyw działania - celem jest oszczędzanie na podatku, nie zaś przyczyny gospodarcze lub osobiste. Jest on formą ucieczki przed podatkiem i z zasady wiąże się $\mathrm{z}$ działaniem organów podatkowych przeciwdziałających temu zjawisku.

„Uchylanie się od podatków to bezpośrednie lamanie prawa podatkowego, działanie nielegalne, sprzeczne z prawem podatkowym. Uchylanie się od podatków polega na obejściu podatków poprzez oszustwo, zatajenie, wprowadzenie w błąd. Identyfikowane jest przez karalność takich czynów, gdyż najczęściej przy uchylaniu powstaje zobowiązanie podatkowe, natomiast nie jest płacony podatek. Uchylając się od opodatkowania, podatnik wykorzystuje dla własnej korzyści błędne przekonanie organu podatkowego, że obowiązek podatkowy w ogóle nie powstał” (Wardak, 2014, s. 52).

Unikanie i uchylanie się od opodatkowania niesie za sobą koszty zarówno przedsiębiorstw, które się tego dopuszczają, jak i państwa, które pobiera dochody $\mathrm{z}$ podatków. Przedsiębiorstwa skupiają się na poszukiwaniu środków prowadzących do zmniejszenia obciążeń podatkowych, zamiast koncentrować się na własnej działalności, rozwoju tej działalności, zwiększaniu poziomu konkurencyjności. Po stronie 
państwa rosną zaś koszty administracyjne wykrywania i zapobiegania nielegalnym praktykom podatkowym (Gebauer, Nam i Parsche, 2007). Organy podatkowe znajdują się pod rosnącą presją zlokalizowania nadużyć podatkowych, zebrania dodatkowych dochodów z podatków, przewidzenia nieprawidłowych zachowań podatników. Jak słusznie zauważa się w literaturze, istnieje związek pomiędzy prowadzoną polityką podatkową państwa a zachowaniami podatników (Gupta, 2008).

System podatku VAT wdrożyło ponad 130 krajów. Doprowadził on do wzrostu o ponad $20 \%$ ogólnych wpływów z podatków. Przyjęcie „podatku VAT” ma pozytywny wplyw na skuteczność systemu podatkowego dla większości krajów stosujących ten podatek (Keen i Lockwood, 2010).

Sytuacja ta dotyczy również Polski. Należy przede wszystkim zwrócić uwagę na znaczenie podatku VAT jako źródła dochodów budżetowych. Wpływy z podatku VAT oraz ich relację do dochodów budżetowych i dochodów podatkowych przedstawia tabela 1.
Powyższe dane pokazują podstawowe znaczenie podatku VAT w zasilaniu dochodów budżetowych. Udział podatku VAT w dochodach ogółem przekracza 45\%, natomiast udział $w$ dochodach podatkowych $-50 \%$. Zauważalny jest znaczny wzrost znaczenia fiskalnego podatku VAT od 2017 roku. Świadczy to o zasadności działań uszczelniających system poboru tego podatku.

Istnieje jednocześnie znaczna możliwość zwiększenia strumienia dochodów w podatku VAT. Wiąże się ona $\mathrm{z}$ istnieniem luki w VAT obrazującej przybliżone dane „w zakresie wysokości strat wynikających z oszustw, unikania i uchylania się od podatku, bankructw, niewypłacalności czy błędów w kalkulacji podatku" (Tratkiewicz, 2016, s. 186). Luka w VAT jest szacowana przez Komisję Europejską, na podstawie raportu przygotowywanego głównie przez fundacje CASE. Poziom luki w VAT został ukazany w tabeli 2.

Według Komisji Europejskiej, w 2016 r. Polska należała do krajów UE z największymi lukami VAT - sięgały one

Tabela 1. Wpływy z podatku VAT do budżetu państwa w porównaniu do dochodów budżetowych i dochodów podatkowych

\begin{tabular}{|l|r|r|r|r|r|}
\hline & $\mathbf{2 0 1 4}$ & $\mathbf{2 0 1 5}$ & $\mathbf{2 0 1 6}$ & $\mathbf{2 0 1 7}$ & $\mathbf{2 0 1 8}$ \\
\hline Dochody budżetowe (mld zł) & 283,5 & 289,1 & 314,7 & 350,4 & 380,1 \\
\hline Dochody podatkowe (mld zł) & 254,8 & 259,7 & 273,1 & 315,3 & 349,9 \\
\hline Dochody z podatku VAT (mld zł) & 124,3 & 123,1 & 126,6 & 156,8 & 176,8 \\
\hline Udział dochodów z podatku VAT w ogóle dochodów (\%) & 43,8 & 42,6 & 40,2 & 44,7 & 46,5 \\
\hline $\begin{array}{l}\text { Udział dochodów z podatku VAT w dochodach } \\
\text { podatkowych (\%) }\end{array}$ & 48,8 & 47,4 & 46,4 & 49,7 & 50,5 \\
\hline Dynamika dochodów z podatku VAT (\%) & - & 99,0 & 102,8 & 123,9 & 127,6 \\
\hline
\end{tabular}

Źródło: MF, 2015-2018; 2019.

Tabela 2. Poziom luki w VAT w Polsce według Komisji Europejskiej

\begin{tabular}{|l|r|r|r|r|r|}
\hline & $\mathbf{2 0 1 2}$ & $\mathbf{2 0 1 3}$ & $\mathbf{2 0 1 4}$ & $\mathbf{2 0 1 5}$ & $\mathbf{2 0 1 6}$ \\
\hline Potencjalne możliwe wpływy z podatku VAT (mld zł) & 159,4 & 158,9 & 162,4 & 166,2 & 167,9 \\
\hline Rzeczywiste wpływy z podatku VAT (mld zł) & 116,3 & 116,6 & 112,7 & 125,8 & 133,0 \\
\hline Luka w VAT (mld zł) & 43,1 & 42,3 & 39,7 & 40,4 & 34,9 \\
\hline $\begin{array}{l}\text { Udział luki w VAT w potencjalnych wpływach z podatku } \\
\text { VAT }(\%)\end{array}$ & 27,0 & 26,7 & 24,4 & 24,3 & 20,8 \\
\hline
\end{tabular}

Źródło: KE, 2018, s. 43.

Wydział Zarządzania UW https://doi.org/10.7172/1733-9758.2018.29.8 
Tabela 3. Poziom luki w VAT w Polsce według PwC

\begin{tabular}{|l|c|c|c|c|c|c|}
\hline & $\mathbf{2 0 1 2}$ & $\mathbf{2 0 1 3}$ & $\mathbf{2 0 1 4}$ & $\mathbf{2 0 1 5}$ & $\mathbf{2 0 1 6}$ & $\mathbf{2 0 1 7}$ \\
\hline Luka w VAT według PwC (mld zł) & 37,5 & 48,0 & 41,3 & 50,4 & 52,0 & 39,0 \\
\hline
\end{tabular}

Źródło: PwC, 2016; PwC, 2017.

34,921 mld zł, co stanowiło 20,8\% teoretycznych, potencjalnych wpływów z podatku VAT (Study, 2018, s. 16). Pomimo tak wysokiego jej poziomu należy zwrócić uwagę na znaczący spadek luki w 2016 r. - nominalnie o 5,5 mld zł, relatywnie o 3,5\%. Ta sytuacja dała Polsce jeden z najlepszych wyników wśród krajów UE (KE, 2018, s. 17). Według szacunków Ministerstwa Finansów w 2017 r. luka podatkowa uległa dalszemu zauważalnemu ograniczeniu, wyniosła około $25 \mathrm{mld}$ zł, tj. około $14,0 \%$ potencjalnych wpływów z podatku VAT (MF, 2018, s. 15).

Poziom luki w VAT w Polsce jest również szacowany przez inne instytucje, przede wszystkim PwC. Wysokość luki według tej instytucji prezentuje tabela 3.

Szacunki PwC również potwierdzają znaczna wysokość luki w VAT w Polsce oraz jej spadek w $2017 \mathrm{r}$.

Przedstawione dane świadcza o znacznej skali nadużyć w zakresie wysokości płaconego podatku VAT. Konieczność jej ograniczenia pokazuje zasadność działań przeciwdziałających zjawisku unikania i uchylania się od tego podatku. Należy również zwrócić uwagę, że podatek VAT jest najbardziej narażony na wszelkiego rodzaju oszustwa i wyłudzenia, spośród wszystkich obowiązujących podatków. Wynika to z samej jego konstrukcji. Mechanizm odliczania podatku naliczonego od podatku należnego powoduje, że podatnicy, zawyżając podatek naliczony, osiągają wymierne korzyści wraz $\mathrm{z}$ rozliczeniem podatku.

W świetle powyższego należy uznać za wręcz oczywiste, że działania państwa skierowane na przeciwdziałanie zjawiskom unikania i uchylania się od opodatkowania skupiły się głównie na podatku VAT.

Warto również podkreślić, że działania mające na celu uszczelnienie systemu poboru podatku VAT zostały podjęte na poziomie Unii Europejskiej. Projekt dyrektywy zmieniającej dyrektywę 2006/112/WE był przedmiotem debaty w Radzie Unii Europejskiej, obecnie zaś jest rozpatrywany przez Parlament Europejski (szerzej: Brach, 2019).
Podejmując działania zapobiegające nadużyciom podatkowym, należy zadbać, aby były one skuteczne. W tym celu należy określić czynniki wpływające na decyzję podatnika płacenia bądź niepłacenia uczciwie podatków. Biorąc pod uwagę czynniki ekonomiczne, opierając się na najczęściej wykorzystywanym do badań modelu stworzonym przez Michaela Allinghama i Angara Sandma (1974, za: Niesiobędzka, 2013, s. 20 i nast.), do czynników tych należą wysokość dochodów, wysokość stawki podatkowej, wysokość kary oraz prawdopodobieństwo kontroli podatkowej. Oprócz czynników czysto ekonomicznych na postawę podatnika wpływają czynniki indywidualne i społeczne, np. moralność podatkowa (szerzej: Niesiobędzka, 2013, s. 38 i nast.).

\section{Zmiany w podatku VAT przeciwdziałające zjawisku unikania i uchylania się od opodatkowania}

Wiele reform w zakresie systemu podatkowego, mających na celu przeciwdziałanie unikaniu i uchylaniu się od opodatkowania, zostało podjętych od 2016 roku. Są to rozwiązania kompleksowe, nie tylko podatkowe, choć odnoszące się głównie do kwestii podatków, jak również związane z konstrukcją poszczególnych podatków. $\mathrm{Z}$ tego punktu widzenia podatek VAT należy do najczęściej zmienianych. Biorąc pod uwagę okres 2016-2018 należy zwrócić uwagę na takie wprowadzone regulacje, jak klauzula zakazu nadużycia prawa w VAT; JPK; pakiet paliwowy; sankcje; rejestracja; mechanizm odwróconego obciążenia; solidarną odpowiedzialność; pakiet przewozowy; mechanizm podzielonej płatności.

\subsection{Klauzula zakazu nadużycia prawa w VAT}

Problem unikania opodatkowania w podatku VAT w pierwszej kolejności ma rozwiązywać klauzula zakazu nadużycia prawa, wprowadzona w obecnej wersji 15 lipca 2016 r. do ustawy o podatku VAT. 
Zgodnie $\mathrm{z}$ art. 5 ust. 4 i 5 ustawy $\mathrm{z}$ dnia 11 marca 2004 r. o podatku od towarów i usług (dalej: ustawa o VAT) przez nadużycie prawa na gruncie podatku VAT rozumie się dokonanie czynności opodatkowanych tym podatkiem, w ramach transakcji, która pomimo spełnienia warunków formalnych ustanowionych $\mathrm{w}$ przepisach ustawy, miała zasadniczo na celu osiagnięcie korzyści podatkowych, których przyznanie byłoby sprzeczne z celem, któremu służą te przepisy. W przypadku wystąpienia nadużycia prawa dokonane czynności opodatkowane VAT-em, wywołuja jedynie takie skutki podatkowe, jakie miałyby miejsce w przypadku odtworzenia sytuacji, która istniałaby w braku czynności stanowiących nadużycie prawa.

Przedstawiona definicja wzorowana jest na definicji sformułowanej przez Trybunał Sprawiedliwości (wyroki C-255/02 Halifax i C-425/06 Part Service). Według niego, aby daną transakcję uznać za nadużycie prawa, należy wykazać, iż zasadniczym jej celem jest uzyskanie korzyści podatkowej. Dla oceny sztucznego charakteru transakcji można uwzględniać również powiązania natury prawnej, ekonomicznej lub personalnej pomiędzy danymi stronami.

Klauzula była przedmiotem orzeczeń sądów administracyjnych w Polsce, które wyjaśniają, jak należy ją stosować. O nadużyciu prawa może być mowa wówczas, gdy działania podmiotu są pozorne i maja na celu wyłącznie uniknięcie opodatkowania lub uzyskanie prawa do odliczenia VAT naliczonego (wyrok WSA w sprawie I SA/Łd 399/18). Nie każda oszczędność podatkowa czy czynność do niej prowadząca stanowi nadużycie prawa w rozumieniu art. 5 ust. 5 ustawy o VAT, a tylko taka, w której działania są pozorne (wyrok WSA w sprawie I SA/Łd 318/18). Sprzedaż zestawu, w którym cena towaru ze stawką $23 \%$ VAT jest zaniżona, a cena innego ze stawka $5 \%$ jest zawyżona, to sztuczne działania mające na celu osiągnięcie korzyści podatkowej (wyrok NSA w sprawie I FSK 1944/15). Na sposób stosowania klauzuli zakazu nadużycia prawa w VAT wskazuje też wyrok NSA z 27 czerwca 2017 r. w sprawie I FSK 1832/15. Kluczowe jest ustalenie, czy faktycznie mamy do czynienia z korzyścia podatkowa w podatku VAT.

Powyższa definicja daje możliwość organom podatkowym kwestionowania transakcji zawartych pomiędzy przedsiębiorstwami, które mają na celu obejście przepisów ustawy o VAT. Jej brzmienie jest bardzo ogólne, dlatego powoduje wiele watpliwości interpretacyjnych. Każdorazowo należy więc brać pod uwage orzecznictwo Trybunału Sprawiedliwości oraz sądów krajowych przy jej stosowaniu. Generalnie taka regulacja jest jednak konieczna, aby można było prowadzić walkę $\mathrm{z}$ nadużyciami w podatku VAT. Ciemną stroną tego rozwiązania jest fakt, iż prowadzić to może do braku pewności u przedsiębiorstw i uznaniowości w decyzjach organów podatkowych.

\subsection{Jednolity Plik Kontrolny (JPK)}

Jednolity Plik Kontrolny wprowadzony ustawa z dnia 10 września 2015 r. o zmianie ustawy - Ordynacja podatkowa oraz niektórych innych ustaw (DzU, poz. 1649 z późn. zm.) to zbiór danych ksiegowych, logistycznych i podatkowych przedsiębiorstwa, przekazywany organowi podatkowemu w postaci elektronicznej. Dane powinny być przedstawione w układzie wymaganym przez Ministerstwo Finansów. Przede wszystkim obejmuje on obowiazek przekazywania ewidencji na potrzeby podatku VAT (rejestr VAT sprzedaży i zakupu). Ponadto księgi rachunkowe, faktury VAT, podatkową księgę przychodów i rozchodów, ewidencję sprzedaży, magazyn i wyciągi bankowe. JPK służy szybkiej analizie transakcji podatnika, porównaniu $\mathrm{z}$ danymi przedstawionymi przez innych przedsiebiorców, jak i danymi dla całej branży. Jest wykorzystywany w prowadzeniu kontroli podatkowych.

Wdrożenie JPK wymaga od przedsiębiorstw znacznych nakładów pracy i nakładów finansowych. Zakres raportowanych danych jest bardzo obszerny według narzuconej struktury, która z reguły nie odpowiada stosowanym $\mathrm{w}$ przedsiębiorstwie systemom informatycznym. Stąd konieczność dostosowania wewnettrznych systemów do wymogów JPK. Nowo założone przedsiębiorstwa powinny wdrożyć system informatyczny w pełni kompatybilny z JPK.

Przechodząc do oceny wprowadzonego rozwiązania, należy zaznaczyć, że w dłuższej perspektywie czasu głównym efektem JPK powinno być usprawnienie wymiany informacji pomiędzy organami podatkowymi, w ten sposób zwiększenie efektywności kontroli podatkowych, przede wszystkim kontroli krzyżowych, które sa bardzo istotne w odniesieniu do podatku VAT. Taki 
skutek wynika z identycznej formy przekazywanych informacji przez podatników, możliwości ich porównań. Ostatecznie nadużycia w podatku VAT powinny być lepiej wykrywane, co należy powiązać ze zwiększeniem wpływów budżetowych z podatku VAT. Negatywnym następstwem wdrożenia JPK są wysokie koszty ponoszone przez ogół przedsiębiorstw. Należy też mieć na uwadze, że JPK nie niesie dla przedsiębiorstw żadnych korzyści, gdyż muszą przerabiać własne systemy na jego potrzeby.

„JPK posiada określony układ i format (schemat xml), który ułatwia jego przetwarzanie, zaś standaryzacja danych pozwala na zastosowanie wobec niego narzędzi analitycznych Dostep do uporzadkowanych danych pozwala na szybsze wykrycie nieprawidłowości oraz przyśpiesza potwierdzanie prawidłowości rozliczeń, czego skutkiem jest m.in. szybsze zwracanie nadpłat podatnikom" (PIE, 2018, s. 18).

\subsection{Pakiet paliwowy}

Największe nadużycia w podatku VAT zostały zidentyfikowane m.in. w obrocie paliwami z zagranicą, dlatego ustawą z dnia 7 lipca 2016 r. o zmianie ustawy o podatku od towarów i usług oraz niektórych innych ustaw (DzU, poz. 1052 z późn. zm.) od 1 sierpnia $2016 \mathrm{r}$. wprowadzono nowe regulacje dotyczące tego zagadnienia. Przede wszystkim koncesję na obrót paliwem z zagranicą może uzyskać podmiot posiadający siedzibę w Polsce. Rozwiązanie to przeciwdziała wykorzystaniu transakcji trójstronnych VAT przez ,znikających podatników". Poza tym podmiot ten musi złożyć zabezpieczenie finansowe i rozliczyć podatek VAT. Ponadto art. 103 ust. 5a ustawy o VAT przewiduje zaliczkę na podatek VAT w związku ze sprowadzeniem paliwa z zagranicy. Rozwiązania te wyeliminowały oszustwa w podatku VAT w obrocie paliwami polegające na ustalaniu podstawionego podatnika.

\subsection{Sankcje w podatku VAT}

Walka z nadużyciami w podatku VAT od 1 stycznia 2017 r. wspierana jest przez ponowne wprowadzenie sankcji w postaci dodatkowego zobowiązania podatkowego, wymierzanego w przypadku nierzetelnego rozliczenia podatku, co nastąpiło na podstawie ustawy z 1 grudnia 2016 r. o zmianie ustawy o podatku od towarów i usług oraz niektórych innych ustaw (DzU, poz. 2024).
Sankcja wymierzana jest od kwoty zaniżenia zobowiąania i standardowo wynosi $30 \%$ tego zaniżenia. W przypadku faktur wystawionych przez podmiot nieistniejący, stwierdzających czynności, które nie miały miejsca, podających kwoty niezgodne z rzeczywistościa, potwierdzajacych czynności pozorne, mające na celu obejście przepisów, sankcja wynosi $100 \%$ kwoty zaniżenia. Podwyższona wysokość sankcji odnosi się do osób świadomie uczestniczących w oszustwach podatkowych. Natomiast standardowa sankcja ma zastosowanie zawsze w przypadku popełnienia błędu $\mathrm{w}$ rozliczeniu. Biorąc pod uwage stopień skomplikowania przepisów o VAT, ich częste nowelizacje, istniejące rozbieżności w orzecznictwie organów podatkowych, jak i sądów administracyjnych, niejednokrotnie określenie prawidłowego traktowania danej transakcji dla celów VAT przysparza problemów nawet profesjonalistom. Ma ona pełne zastosowanie do uczciwych podatników, którzy popełnili błąd.

Podwyższona stawka sankcji ma na celu penalizację ewidentnych nadużyć dokonywanych przez podatników świadomie biorących udział w nieuczciwych transakcjach (co uzasadnia określenie sankcji tej wysokości - odpowiadającej wysokości uszczuplenia wpływu do budżetu). Podwyższone sankcje nie będą stosowane w odniesieniu do podatników biorących udział w takich transakcjach nieświadomie (podmioty takie czesto sa wykorzystywane w takich procederach), tj. podatników działających w dobrej wierze (wyrok WSA w sprawie I SA/Sz 873/18).

\subsection{Rejestracja na potrzeby podatku VAT}

Rejestracja na potrzeby podatku VAT uprawnia do odliczania podatku naliczonego. Od 1 stycznia 2017 r. na podstawie ustawy z 1 grudnia 2016 r. o zmianie ustawy o podatku od towarów i usług oraz niektórych innych ustaw (DzU, poz. 2024) zaostrzono przepisy dotyczące rejestracji, w szczególności wprowadzono obowiązek weryfikacji danych podanych w zgłoszeniu rejestracyjnym. Ponadto ustalono sytuacje obligatoryjnej odmowy rejestracji oraz obligatoryjnego wykreślenia podatnika z rejestru. Dotyczą one sytuacji, kiedy podmiot (podatnik) nie istnieje, nie można się z nim skontaktować, dane podane w zgłoszeniu sa niezgodne $\mathrm{z}$ prawda czy nie stawia sie na wezwanie. Przepisy te mają na celu 
wyeliminowanie podmiotów (podatników), którzy mogliby uczestniczyć w nadużyciach w podatku VAT.

Aby odmowę identyfikacji podatnika poprzez nadanie indywidualnego numeru można było uznać za proporcjonalną wobec celu polegającego na zapobieganiu oszustwom podatkowym, musi ona opierać się na poważnych przesłankach pozwalajacych obiektywnie stwierdzić istnienie prawdopodobieństwa, iż nadany temu podatnikowi numer identyfikacji podatkowej VAT zostanie wykorzystany do popełnienia oszustwa (wyrok WSA w sprawie I SA/Bk 1229/17).

\subsection{Mechanizm odwróconego obciążenia}

Zgodnie $\mathrm{z}$ art. 17 ust. 1 pkt 7 i 8 istota odwróconego obciążenia polega na tym, że podatek związany z czynnością opodatkowaną nie jest rozliczany przez dostawce lub usługodawcę, lecz rozlicza go nabywca towarów lub usługobiorca. Nabywca musi zatem podatek VAT wynikający z zakupów wykazać jako podatek należny, czyli w konsekwencji go zapłacić. Jednocześnie wykazuje go jako podatek naliczony w zakresie, w jakim przysługuje mu prawo do odliczenia. Naturalnie rozwiązanie to komplikuje nabywcy rozliczenie podatku VAT. Mechanizm ten dotyczy wybranych towarów i usług, przy czym ich katalog jest systematycznie rozszerzany. Obejmuje on głównie wyroby stalowe, metale, wyroby elektroniczne, odpady i surowce wtórne, usługi budowlane.

Zastosowanie mechanizmu odwróconego obciążenia zawiera orzeczenie WSA w sprawie III SA/Wa 745/16. Zgodnie z nim mechanizm odwrotnego obciążenia podatkiem od towarów i usług stanowi odstępstwo od generalnej zasady wyrażonej w art. 193 dyrektywy 2006/112/WE w sprawie wspólnego systemu podatku od wartości dodanej2 ${ }^{2}$ i przenosi obowiązek rozliczenia VAT należnego ze sprzedającego na nabywcę. Podstawą dla zastosowania tego szczególnego środka jest art. 199-199a dyrektywy. W myśl art. 199a ust. 1 lit e dyrektywy 2006/112/WE w sprawie wspólnego systemu podatku od wartości dodanej mechanizm odwrotnego obciążenia VAT może mieć zastosowanie do dostawy gazu i energii elektrycznej na rzecz podatnika-pośrednika, zgodnie $\mathrm{z}$ definicją art. 38 ust. 2 dyrektywy, na rzecz którego jest wykonywana. Ustawodawca krajowy, wprowadzając do ustawy o podatku od towarów i usług art. 17 ust. 1 pkt 7, skorzystał z możliwości prawnej uczynienia podatnikiem podatku od towarów i usług odbiorcy dostawy, ale jedynie w odniesieniu do towarów wymienionych w załaczniku nr 11 do ustawy, dokonując w tym zakresie implementacji przepisów prawa wspólnotowego do porządku krajowego.

\subsection{Sytuacje solidarnej odpowiedzialności}

Solidarna odpowiedzialność w podatku VAT występuje głównie w dwóch obszarach - odnosi się do nabywcy towarów oraz dotyczy pełnomocnika składającego zgłoszenie rejestracyjne podatnika VAT.

Wprowadzenie do podatku VAT solidarnej odpowiedzialności nabywcy towarów za zaległości podatkowe sprzedającego nastąpiło 1 października 2013 r. na podstawie ustawy z dnia 26 lipca 2013 r. o zmianie ustawy o podatku od towarów i usług oraz niektórych innych ustaw (DzU, poz. 1027). Rozwiązanie to ma na celu zwiększenie odpowiedzialności podatników wynikającej z zawieranych przez nich transakcji. Powinna ona prowadzić do stopniowej eliminacji z obrotu gospodarczego podmiotów dopuszczających się nadużyć w podatku VAT. Podstawowym warunkiem istnienia odpowiedzialności nabywcy zgodnie $\mathrm{z}$ art. 105a ustawy o VAT jest posiadanie wiedzy lub uzasadnionej podstawy do przypuszczenia, że kwota podatku VAT związana $\mathrm{z}$ daną transakcją nie będzie przez sprzedajacego wpłacona. Powinny wskazywać na to okoliczności zawarcia transakcji, w szczególności zaniżona cena. Solidarna odpowiedzialność związana jest z nabyciem ściśle określonych towarów, do których przede wszystkim należą wybrane wyroby stalowe, paliwa i wyroby elektroniczne. Katalog tych towarów był rozszerzany w latach 2016-2018.

Niewątpliwie podstawowym zagrożeniem istnienia takiej odpowiedzialności jest objęcie nią podmiotów uczciwie rozliczających się $\mathrm{z}$ podatku, niebędących $\mathrm{w}$ stanie przewidzieć rozmaitych negatywnych sytuacji wiążących się z transakcjami gospodarczymi.

Solidarną odpowiedzialność z podatnikiem VAT ponosi również pełnomocnik, który złożył zgłoszenie rejestracyjne tego podatnika. Odpowiedzialność jest ograniczona do kwoty 500 tys. zł oraz obowiązuje przez 6 miesięcy od dnia zarejestrowania. Ponadto odpowiedzialność istnieje, 
jeżeli powstanie zaległości podatkowych wiązało się $\mathrm{z}$ uczestnictwem podatnika $\mathrm{w}$ nierzetelnym rozliczaniu podatku w celu odniesienia korzyści majątkowej. Wprowadzenie 1 stycznia 2017 r. na podstawie ustawy z 1 grudnia 2016 r. o zmianie ustawy o podatku od towarów i usług oraz niektórych innych ustaw (DzU, poz. 2024) tej odpowiedzialności ma dotyczyć przede wszystkim pełnomocników, którzy świadomie pomagają przy rejestracji firm osób fizycznych lub firm osób prawnych, powstających tylko w celu uczestnictwa w oszustwach podatkowych. Często są to osoby podstawione, nieświadome prowadzonych działań, cały proceder jest zaś prowadzony przez prawdziwych oszustów sprawujących pełną kontrolę organizacyjną i finansową.

\subsection{Pakiet przewozowy}

Wśród stwierdzonych nieprawidłowości w zakresie podatku VAT i podatku akcyzowego występują dotyczące obrotu towarami wrażliwymi, do których należą przede wszystkim paliwa płynne (paliwa silnikowe, paliwa opałowe), oleje (oleje smarowe), alkohol (wyroby zawierające alkohol etylowy, np. rozpuszczalniki oraz alkohol etylowy całkowicie skażony), tytoń (susz tytoniowy). Wprowadzony 18 kwietnia $2017 \mathrm{r}$. na podstawie ustawy z dnia 9 marca $2017 \mathrm{r}$. o systemie monitorowania drogowego przewozu towarów (DzU, poz. 798 z późn. zm.) tzw. pakiet przewozowy nakłada na podmioty zajmujące się obrotem tymi towarami obowiązki dokumentacyjne służące monitorowaniu przewozu.

\subsection{Mechanizm podzielonej płatności}

Mechanizm podzielonej płatności, obowiązujący od 1 lipca 2018 r. na podstawie ustawy z 15 grudnia 2017 r. o zmianie ustawy o podatku od towarów i usług oraz niektórych innych ustaw (DzU 2018, poz. 62 z późn. zm.), polega na podzieleniu przez nabywcę kwoty należnej dostawcy lub usługodawcy na dwie części: kwotę netto oraz kwotę odpowiadającą podatkowi VAT. Kwota odpowiadająca podatkowi VAT wpłacana jest na specjalnie wyodrębniony rachunek VAT. Celem takiego rozwiązania jest ograniczenie i poddanie kontroli sposobu wykorzystania środków znajdujących się na rachunku VAT. Środki te generalnie mogą być wykorzystywane do regulowania płatności na rzecz budżetu państwa. Wyprowadzenie środków z rachunku VAT na stan- dardowe konto bankowe odbywa się pod nadzorem organu podatkowego - wyraża na to zgodę naczelnik urzędu skarbowego w drodze postanowienia na wniosek podatnika. Postanowienie takie jest wydawane w ciagu 60 dni od otrzymania wniosku.

Omawiany mechanizm rozliczenia jest rozwiązaniem dobrowolnym, nabywca towarów i usług decyduje, jak dokona zapłaty. Celem wprowadzenia tej regulacji jest zapewnienie prawidłowości rozliczenia podatku VAT, zabezpieczenie jego wpłaty do budżetu państwa. Negatywnym skutkiem zastosowania tego mechanizmu jest pogorszenie płynności finansowej przedsiębiorstw. Należy jednak zauważyć, że ustawodawca wprowadził zachęty do stosowania tego rozliczenia. Wśród nich jest zwrot nadwyżki podatku VAT w ciągu 25 dni oraz ograniczenie stosowania odpowiedzialności solidarnej i sankcji VAT.

Zmiany w podatku VAT związane z przeciwdziałaniem unikaniu i uchylaniu się od opodatkowania dotyczyły również innych regulacji niż wyżej omówione, przy czym są to przepisy funkcjonujące od dłuższego czasu. Zmiany te polegały na ich udoskonaleniu, aby lepiej służyły wspomnianym celom. Do takich zmian należy zaliczyć obowiązek prowadzenia ewidencji oraz składania deklaracji i informacji podsumowujących w formie elektronicznej, ograniczenie kwartalnego rozliczenia $\mathrm{z}$ podatku, likwidacja możliwości składania informacji podsumowujących za okresy kwartalne, zasady zwrotu podatku i jego terminów.

Oprócz wyżej wskazanych zmian wprowadzonych do ustawy o podatku VAT, nastapiły zmiany $w$ innych ustawach mające duże znaczenie w odniesieniu do podatku VAT. Należy tutaj przede wszystkim przytoczyć nowelizacje kodeksu karnego i kodeksu karnego skarbowego, które znacznie zaostrzyły kary za przestępstwa przeciwko wiarygodności faktur. Ponadto powstanie Krajowej Administracji Skarbowej zmieniło zasady prowadzenia kontroli podatkowych, stawiając głównie na ich efektywność.

\section{Ocena zmian w podatku VAT przeciwdziałajacych unikaniu i uchylaniu się od opodatkowania}

Przedstawione zmiany w podatku VAT świadczą o znacznym zaangażowaniu ustawodawcy $\mathrm{w}$ walkę $\mathrm{z}$ nadużyciami $\mathrm{w}$ tym 
podatku. Zmiany dokonywane są w szerokim zakresie i dotyczą zarówno wszystkich podatników, jak i wybranych z określonych branż, obejmują wszystkie transakcje oraz poszczególne ich rodzaje, wkraczaja bezpośrednio w cały system rozliczenia podatku, ustalając zasady jego dokonywania. Generalnie taką postawę ustawodawcy należy ocenić bardzo pozytywnie. Unikanie i uchylanie się od opodatkowania niesie za soba szereg konsekwencji dla wszystkich stron stosunku podatkowego. Walka $\mathrm{z}$ tą patologią $\mathrm{w}$ prawie podatkowym powinna być realizowana przede wszystkim ze strony podmiotu czynnego, czyli państwa. Bierna postawa państwa zasługiwałaby na krytykę. Jednakże równie ważną kwestią jest sposób, w jaki ustawodawca tę walkę prowadzi. W szczególności skuteczność wprowadzonych rozwiązań oraz konsekwencje dla uczciwych podatników.

Przechodząc do skuteczności wprowadzonych zmian i odnosząc je do modelu Allinghama i Sandma należy stwierdzić, że wśród czynników modelowych zmiany obejmowały wysokość kary oraz prawdopodobieństwo kontroli podatkowej. Kary za nadużycia podatkowe zostały drastycznie podwyższone, szczególnie w zakresie odpowiedzialności karnej. Prawdopodobieństwo kontroli podatkowej wzrosło, $\mathrm{z}$ uwagi na zwiększony zakres informacji przekazywanych organom podatkowym. Natomiast ustawodawca nie obniżył stawek podatkowych, wręcz przeciwnie, przedłużył obowiązywanie podwyższonych stawek. Podstawowa stawka w podatku VAT w Polsce jest jedną z najwyższych w Unii Europejskiej i najprawdopodobniej przyczynia sie do wzrostu nadużyć w podatku VAT.

Niewątpliwie argumentem przemawiajacym za skutecznością podjętych działań jest znaczny wzrost wpływów z podatku VAT w 2017 r. i utrzymanie wzrostu w 2018 r. oraz zmniejszenie luki podatkowej $\mathrm{w}$ podatku VAT w 2017 roku.

Biorąc pod uwagę szeroki zakres wprowadzanych zmian, należy ocenić, w jakim stopniu przyczyniają się one do zwiększenia pewności prawa. Unikanie i uchylanie się od opodatkowania z samej swojej istoty burza właściwy porzadek związany z ponoszeniem danin publicznych. Brak przepisów przeciwdziałających takim procederom należy uznać za prowadzący do braku pewności prawa. Podjęte intensywne działania legislacyjne w omawianym zakresie zwięk- szają zatem pewność prawa. Jednakże omawiane przepisy - głównie klauzula zakazu nadużycia prawa w VAT czy sytuacje solidarnej odpowiedzialności naznaczone niepewnością co do ich zastosowania - sformułowane są w sposób nieostry i trudno przewidzieć skutki ich działań. Taka ich konstrukcja jest nieunikniona. Wobec tego ważną kwestia jest takie ich stosowanie przez organy podatkowe, aby były adresowane do osób nadużywających prawo, a nie popełniających błąd. Ważna jest kontrola sądowa decyzji podatkowych wydanych na podstawie tych przepisów, która ostatecznie ma tę pewność zapewnić. Wskazuje na to Trybunał Sprawiedliwości stwierdzając, że walka z oszustwem, unikaniem opodatkowania i ewentualnymi nadużyciami jest $\mathrm{z}$ jednej strony celem uznanym $i$ wspieranym przez prawo unijne, $z$ drugiej zaś - prawo unijne powinno być również precyzyjne, a jego stosowanie możliwe do przewidzenia przez podmioty (wyrok C-301/97 Królestwo Niderlandów). Należy również wspomnieć o możliwości skorzystania $\mathrm{z}$ wydanych interpretacji podatkowych, które wyjaśniają, jak należy rozumieć dane przepisy i jak je stosować w praktyce.

Kolejną konsekwencją wprowadzenia omawianych przepisów jest znaczne dalsze skomplikowanie konstrukcji podatku VAT. Stosowanie w praktyce podatku VAT staje się dla przedsiębiorstw coraz bardziej uciążliwe, wymaga ponoszenia coraz większych kosztów, dostosowania sie do narzuconych reguł. Część z wprowadzonych zmian to niestandardowe rozwiazania w podatku VAT, po części sprzeczne $\mathrm{z}$ samą istotą tego podatku - należa do nich np. mechanizm odwróconego obciążenia. W tej sytuacji wymóg zapłaty podatku jest przesunięty ze sprzedającego na kupującego, co niesie za sobą odpowiedzialność za tę zapłate po stronie kupującego. Nabywca $z$ tytułu tej samej transakcji ma podatek naliczony oraz podatek należny. Konsekwencje te odczuwają wszyscy podatnicy.

Należy również zwrócić uwagę, że nowe wymogi wiążą się z ponoszeniem większych kosztów przez przedsiębiorstwa. Wdrożenie JPK, elektronicznych deklaracji czy pakietu przewozowego wymaga zmian systemów informatycznych w przedsiębiorstwach.

Skutkiem omawianych zmian jest także rosnąca odpowiedzialność przedsiębiorcy za prawidłową wysokość zapłaconego podatku VAT przez zarówno niego, jak i jego 
kontrahentów, a więc samo prowadzenie działalności gospodarczej staje się bardziej ryzykowne. Należy zadbać o należytą staranność w ocenie kontrahentów, w ocenie warunków transakcji, aby być przekonanym, że nie służy ona unikaniu lub uchylaniu się od opodatkowania. Zadbanie o należytą staranność generalnie niesie za sobą konieczność poniesienia kosztów takich działań.

Przedstawione powyżej konsekwencje omawianych zmian w podatku VAT pozwalają wysnuć wniosek, że relatywnie największe problemy $\mathrm{z}$ ich praktycznym wdrożeniem mają najmniejsze przedsiębiorstwa (w szczególności mikro i małe). W przypadku prowadzenia działalności w niewielkiej skali znaczenia nabiera prostota podatku (prosta ewidencja, proste rozliczanie). Brak wyspecjalizowanych służb księgowych i podatkowych utrudnia ocene kontrahentów, transakcji czy spełnienie wymogów dotyczących sporządzania różnych dokumentów oraz bieżące monitorowanie wprowadzanych zmian w podatku.

Jednocześnie należy podkreślić wprowadzanie partnerskiego współdziałania administracji podatkowej z podatnikami.

„Administracja staje sie coraz bardziej przyjazna przedsiębiorcy, znajduje kolejne pola współpracy. Dotyczy to w szczególności walki z wyłudzeniami VAT, które nie tylko szkodzą Skarbowi Państwa, ale również zaburzają rynkowe warunki konkurencji. Tworzone są nowe platformy współdziałania (Centrum Obsługi Kluczowych Podmiotów), pojawiają sie nowe funkcjonalności: scentralizowana informacja podatkowa, publikacja ostrzeżeń i objaśnień podatkowych, wspólnie tworzony jest katalog dobrych praktyk podatnika VAT. Administracja podatkowa udostępnia również przedsiębiorcom kolejne narzędzia pozwalajace na weryfikacje rzetelności ich biznesowych partnerów" (PIE, 2018, s. 26).

Należy mieć na uwadze konieczność dalszych działań mających na celu uszczelnienie systemu poboru podatku VAT w Polsce, co podkreśla się w literaturze.

„Konieczne działania, które przyniosłyby pożądane rezultaty w zakresie faktur „pozorowanych” i ,pustych” faktur, to centralizacja i automatyzacja kontroli. Najbardziej skutecznym sposobem na jej realizację jest wprowadzenie centralnego rejestru faktur, który oznaczałby skorelowanie momentu wystawienia faktury z jej przesyłem na serwer administracji podatkowej z jednoczesnym jej udostępnieniem na konto podatkowe nabywcy towaru lub usługi. Wystawienie i przesył mógłby nastąpić jedynie przez stosowne uwierzytelnienie operacji, co wykluczyłoby „podszywanie” się przestępców pod legalnie działające podmioty. Warunkiem odliczenia podatku przez nabywce byłoby „posiadanie" faktury na swoim koncie podatkowym" (Tratkiewicz, 2016, s. 190).

\section{Podsumowanie}

Przegląd zmian w podatku VAT skierowanych na ograniczenie unikania i uchylania się od opodatkowania pozwala na przedstawienie następujących wniosków.

1. Działania państwa skierowane przeciwko unikaniu i uchylaniu się od opodatkowania skupione są głównie na podatku VAT. Taką decyzję należy uznać za słuszną, gdyż podatek ten charakteryzuje się największą skalą nadużyć. Ponadto jest najbardziej wydajnym fiskalnie podatkiem i podjęte działania mogą tę wydajność jeszcze znacznie poprawić.

2. Zastosowano szeroki zakres zmian w podatku VAT przeciwdziałających nadużyciom podatkowym. Ponadto zmiany obejmują znaczne zaostrzenie przepisów karnych. W konsekwencji w latach 2017-2018 widoczne są efekty podjętych działań w postaci wyższych wpływów do budżetu i mniejszej luki podatkowej.

3. Wprowadzone zmiany w podatku VAT, mające na celu przeciwdziałanie nadużyciom podatkowym, pogłębiają stopień skomplikowania konstrukcji i rozliczania tego podatku. Odczuwają to wszystkie przedsiębiorstwa. Wiąże się to $\mathrm{z}$ ponoszeniem wyższych kosztów obsługi tego podatku.

4. Wprowadzone zmiany w podatku VAT, mające na celu przeciwdziałanie nadużyciom podatkowym, niosą za sobą pozytywne i negatywne skutki dla podatników. Zmniejszając zakres nadużyć podatkowych, przywracają konkurencję na rynku. Zwiększają ryzyko prowadzonej działalności poprzez wzrost odpowiedzialności za prawidłowe rozliczenie podatku od danej transakcji. Posługując się nieostrymi pojęciami, powodują niepewność co do ich zastosowania.

5. Biorąc pod uwage konsekwencje wprowadzonych zmian, szczególną ochroną ustawodawcy powinni być objęci uczciwi podatnicy, a wśród nich przede wszystkim najmniejsze przedsiębiorstwa (głównie mikro i małe). Wprowadzone w wyniku zmian nowe wymogi w podatku VAT są 
bardziej odczuwalne wśród mniejszych podmiotów, które nie posiadają rozbudowanego zaplecza organizacyjnego i finansowego.

\section{Przypisy}

1 Art. 2 ustawy z dnia 6 marca 2018 r. - Prawo przedsiębiorców (DzU, poz. 646 z późn. zm.).

2 Zgodnie z którym osobą zobowiązaną do zapłaty VAT jest podatnik dokonujący dostawy towarów lub świadczenia usług.

\section{Bibliografia}

Brach, A. (2019). Projektowane kierunki zmiany dyrektywy 2006/112/WE mające na celu uszczelnienie systemu poboru podatku. Przeglad Podatkowy, 2(334), 33-38.

Brzeziński, B. (2003). Wstęp do nauki prawa podatkowego. Toruń: TNOiK.

Filipczyk, H. (2017). Tax avoidance and rationality of law. Warszawa: Wolters Kluwer.

Gebauer, A., Nam, C.W. i Parsche, R. (2007). Can reform models of value added taxation stop the VAT evasion and revenue shortfalls in the UE? Journal of Economic Policy Reform, 10, 1-13.

Gupta, R. (2008). Tax evasion and financial repression. Journal of Economics and Business, 60, 517-535.

Karwat, P. (2002). Obejście prawa podatkowego. Warszawa: Dom Wydawniczy ABC.

KE. (2018). Study and Reports on the VAT Gap in the EU-28 Member States: 2018 Final Report. TAXUD/2015/CC/131. Brussels: European Commissions.

Keen, M. i Lockwood, B. (2010). The value added tax: its causes and consequences. Journal od Development Economics, 92, 138-151.

Kuźniacki, B. (2012). Skuteczność polskich ogólnych norm podatkowoprawnych jako narzędzi potencjalnie służących zwalczaniu unikania opodatkowania przez wykorzystanie kontrolowanych spółek zagranicznych. Toruński Rocznik Podatkowy.

Larkins, E.R. (1991). Multinationals and their Quest for the Good Tax Haven: Taxes are but One, Albeit an Important, Consideration. International Lawyer, 25.

MF. (2015-2018). Sprawozdanie $z$ wykonania budżetu państwa za poszczególne lata. Warszawa: Ministerstwo Finansów.

MF. (2018). Wieloletni Plan Finansowy Państwa na lata 2018-2021. Warszawa: Ministerstwo Finansów.
MF. (2019). Szacunkowe dane o wykonaniu budże tu państwa za styczeń-grudzień 2018 r. Warszawa: Departament Budżetu Państwa, Ministerstwo Finansów.

Niesiobędzka, M. (2013). Dlaczego nie ptacimy podatków? Psychologiczna analiza uchylania się od opodatkowania. Warszawa: Wydawnictwo Naukowe Scholar.

PIE. (2018). Zmniejszenie luki VAT w Polsce w latach 2016-2017. Warszawa: Polski Instytut Ekonomiczny.

PwC. (2016). Wytudzenia VAT - luka podatkowa w 2016 r. i prognoza na 2017 r., PwC. Pozyskano z: https://www.pwc.pl/pl/media/2017/2017-10-19-pwcluka-vat-2017.html (10.04.2019).

PwC. (2017). Luka VAT w Polsce w 2017 r. zmniejszy sie o ok. 13 mld zt. PwC. Pozyskano z: https:// www.pwc.pl/pl/media/2017/2017-10-19-pwc-lukavat-2017.html (10.04.2019).

Tipke, K. i Kruse, H. (1996). Abgabenordnung. Kommentar. Koln: Dr Otto Schmidt.

Tratkiewicz, T. (2016). Luka w VAT - sposoby przeciwdziałania w Polsce i Unii Europejskiej. Studia Ekonomiczne. Zeszyty Naukowe Uniwersytetu Ekonomicznego w Katowicach, 294, 185-196.

Ustawa z dnia 11 marca 2004 r. o podatku od towarów i usług (t.j. 2018, poz. 2174 z późn. zm.).

Wardak, Z. (2014). Karnoskarbowa i kryminologiczna problematyka oszustwa podatkowego. Łódź: Wydział Prawa i Administracji Uniwersytetu Lódzkiego.

Wyrok NSA z dnia 27 czerwca 2017 r. w sprawie I FSK 1832/15.

Wyrok NSA z dnia 27 lipca 2017 r. w sprawie I FSK 1944/15.

Wyrok Trybunału Sprawiedliwości w sprawie C-255/02 Halifax, EU: C:2006:121.

Wyrok Trybunału Sprawiedliwości w sprawie C-301/97 Królestwo Niderlandów, EU: C:2001:621.

Wyrok Trybunału Sprawiedliwości w sprawie C-425/06 Part Service, EU: C:2008:108.

Wyrok WSA z Białegostoku z dnia 21 lutego $2018 \mathrm{r}$. w sprawie I SA/Bk 1229/17

Wyrok WSA z Łodzi z dnia 13 czerwca 2018 r. w sprawie I SA/Ld 318/18.

Wyrok WSA z Łodzi z dnia 19 stycznia 2018 r. w sprawie I SA/Łd 399/18.

Wyrok WSA z Warszawy z dnia 22 czerwca 2016 r w sprawie III SA/Wa 745/16.

Wyrok WSA ze Szczecina z dnia 21 lutego 2019 r w sprawie I SA/Sz 873/18. 